\title{
COVID-19 Outbreak in a Large Penitentiary Complex, April-June 2020, Brazil
}

Fernando A. Gouvea-Reis, Patrícia D. Oliveira, Danniely C.S. Silva, Lairton S. Borja, Jadher Percio, Fábio S. Souza, Cássio Peterka, Claudia Feres, Janaína de Oliveira, Giselle Sodré, Wallace dos Santos, Camile de Moraes

An outbreak of coronavirus disease began in a large penitentiary complex in Brazil on April 1, 2020. By June 12 , there were 1,057 confirmed cases among inmates and staff. Nine patients were hospitalized, and 3 died. Mean serial interval was $\approx 2.5$ days; reproduction number range was 1.0-2.3.

Detim etention facilities constitute an environment optimal for the introduction and spread of respiratory infectious diseases. Living conditions of inmates are frequently overcrowded and poorly ventilated, might provide limited access to running water, and lack adequate sanitary facilities. These conditions increase risk factors for and background prevalence of infection $(1,2)$. Furthermore, prisons commonly must deal with understaffing and lack of resources, presenting additional challenges to triaging and treating higher-risk patients in a timely manner (3).

The first case of coronavirus disease (COVID-19) in Brazil was reported on February 26, 2020. The introduction of severe acute respiratory syndrome coronavirus 2 (SARS-CoV-2), the causative agent of COVID-19, into prisons adds an extra burden into an already overwhelmed environment. COVID-19 could be introduced through staff, visitors, or inmates under a semi-open regime, in which they spend the day outside the penitentiary complex and return in the evening. In addition, a new disease for which there is no existing immunity increases the health risk. Therefore, control of COVID-19 in prisons must be consid-

Author affiliations: Ministério da Saúde, Brasília, Brazil

(F.A. Gouvea-Reis, P.D. Oliveira, D.C.S. Silva, L.S. Borja,

J. Percio, C. de Moraes); Secretaria de Estado de Administração

Penitenciária, Brasília (F.S. Souza); Secretaria de Estado da

Saúde do Distrito Federal, Brasília (C. Peterka, C. Feres, J. de

Oliveira, G. Sodré, W. dos Santos)

DOI: https://doi.org/10.3201/eid2703.204079 ered an essential part of a public health response (4).

In Brazil, $\approx 750,000$ people are imprisoned in a system built to hold just over 442,000 (5). By June 12, Brazil had reported 828,810 COVID-19 cases nationwide, with $>2,200$ of those within prison settings $(6,7)$. Testing in Brasília, located in Brazil's Federal District, accounted for $65.5 \%$ of all COVID-19 tests performed among imprisoned persons; $\approx 48 \%$ of the total national cases in prisons were reported in a maximum-security penitentiary complex in Brasília. The complex includes 4 prison units: Unit I houses persons under pretrial detention, Unit II houses inmates under a semi-open regime, and Units III and IV house convicted inmates. Overall, the prison is one of the largest penitentiary complexes in Brazil, housing $>13,000$ male inmates, as of June 2020.

In this report, we provide a descriptive analysis of the outbreak and estimate the disease transmissibility in its early stages. Data were collected from secondary sources, including the penitentiary monitoring dataset for COVID-19 notifications, the penitentiary administration system, and the monitoring resources of the healthcare system. The public health response was a joint effort from the state health and security departments, local health and security teams, and the Brazil Ministry of Health's Brazilian Field Epidemiology Training Program. Ethics approval was obtained under CONEP (Comissão Nacional de Ética em Pesquisa [National Research Ethics Commission], protocol number 37007220.1.0000.0008).

\section{The Study}

The first COVID-19 case in Brasília was reported on March 5; on April 1, the first case in the penitentiary complex, in a prison guard, was confirmed. The earliest infections occurred among security officers; the first inmate with COVID-19 was reported on April 7 in Unit I, the pretrial detention area. Six cases were 
reported on April 10 in 2 different wings from the same block in that unit. The location of the first cases in the other prison units indicated that COVID-19 had dispersed across the penitentiary complex. In Unit II, 13 cases were reported on April 9-10 in 3 different blocks. In Unit III, 5 cases were confirmed on April 17 in 2 different blocks. In Unit IV, 6 cases were confirmed on April 15-17 in 3 different blocks. Although the virus was not introduced inside the penitentiary complex until $\approx 1$ month after the first reported case in Brasilia, the complex rapidly attained the highest incidence in the region. By May 1 , whereas the incidence rate was 47 cases $/ 100,000$ persons in the city, it was 1,832 cases $/ 100,000$ persons among inmates (8).

During April 1-June 12, there were 1,057 reported cases at the prison: $859(81.3 \%)$ in inmates, 180 $(17.1 \%)$ in prison guards, $9(0.8 \%)$ in contracted staff, and $9(0.8 \%)$ in health professionals. Distribution of the symptomatic cases over time is shown in Figure 1. Nine patients were hospitalized, and 3 deaths were reported: 1 prison guard and 2 inmates.

Among infected inmates, mean age was 38 years (SD 14.1 years); 296 (34.5\%) were $18-29$ years of age, 245 (28.5\%) 30-39 years, 124 (14.4\%) 40-49 years, 61 (7.1\%) 50-59 years, and $133(15.5 \%) \geq 60$ years. Information about ethnicity was available for 783 patients; 407 (52.0\%) were mixed race, 214 (27.3\%) White, 93 (11.9\%) Asian, 67 (8.5\%) Black, and 2 (0.3\%) Indigenous. Underlying medical conditions were reported in $160(18.6 \%)$ patients; the most prevalent were cardiovascular diseases $(11.8 \%)$, diabetes $(5.1 \%)$, and pneumopathies $(2.8 \%)$. We were able to evaluate the presence of symptoms on medical records from 401 patients with confirmed COVID-19 cases. The most prevalent symptoms were headache $(34.9 \%)$, cough $(30.2 \%)$, and fever $(28.9 \%)$ (Table).

We applied the EpiEstim R package (https:// cran.r-project.org) to estimate the reproduction number over time $\left(R_{t}\right)$, the number of secondary PCR-confirmed cases resulting from a single initial case, for the penitentiary complex. We estimated the serial interval by computing the difference between the dates of symptom onset for pairs of primary and secondary infected inmates in 144 cases confirmed by reverse transcription PCR (RT-PCR) recorded in April, during the early stages of the outbreak, within all 4 prison units. We identified the primary infected inmate as the person in a cell having the first RT-PCRconfirmed case; we identified secondary infected inmates as anyone sharing a cell with a primary case patient who tested positive for COVID-19 by RT-PCR $\leq 14$ days after symptom onset in the cellmate. Local health teams identified suspected cases through daily active case finding; patients with confirmed cases were isolated as separate cohorts.

We estimated the mean serial interval at 2.51 days (SD 1.21). We found high transmissibility at the start of the outbreak, when the overall $R_{t}$ was 2.28 in the prison complex (Figure 2). April was the

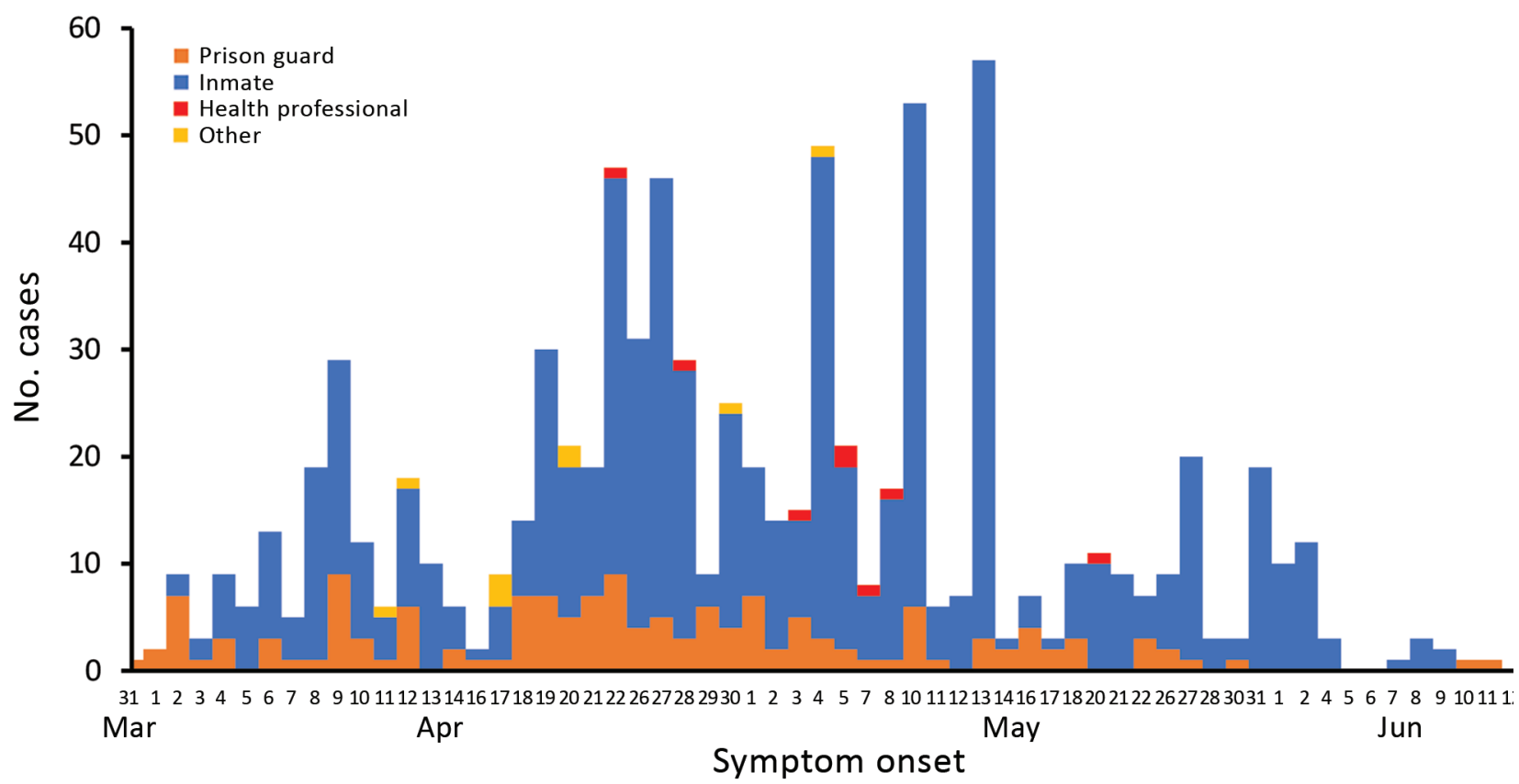

Figure 1. Distribution of symptomatic coronavirus disease cases over time by symptom onset date in a penitentiary complex, Brasília, Brazil, March-June 2020. 
Table. Characteristics of coronavirus disease cases within the penitentiary complex, Brasília, Brazil, AprilJune 2020

\begin{tabular}{lcc}
\hline Characteristic & No. & \% Total \\
\hline Age, y & 296 & 34.5 \\
$18-29$ & 245 & 28.5 \\
$30-39$ & 124 & 14.4 \\
$40-49$ & 61 & 7.1 \\
$50-59$ & 133 & 15.5 \\
$\geq 60$ & & \\
\hline Ethnicity & 93 & 11.9 \\
Asian & 214 & 27.3 \\
White & 2 & 0.3 \\
Indigenous & 407 & 52.0 \\
Mixed race & 67 & 8.5 \\
Black & 140 & \\
\hline Symptoms $†$ & 121 & 34.9 \\
Headache & 116 & 30.2 \\
Cough & 79 & 28.9 \\
Fever & 67 & 19.7 \\
Ageusia/anosmia & 42 & 16.7 \\
Dyspnea & 32 & 10.5 \\
Myalgia & 23 & 8.0 \\
Sore throat & 16 & 5.7 \\
Nasal congestion & & 4.0 \\
Diarrhea & 101 & 11.8 \\
\hline Underlying health conditions & & 5.1 \\
Cardiovascular disease & 44 & 2.8 \\
Diabetes & 24 & 0.9 \\
Pneumopathies & 8 & \\
Others & & \\
\hline Da & & \\
\hline
\end{tabular}

${ }^{*}$ Data available for 783 cases.

†Data available for 401 cases.

łIncludes metabolic disorders, immunosuppression, psychiatric disease, and chronic hepatitis.

month with the most intense transmission; Units III and IV reported 149 cases during April 20-30, which is reflected in the $R_{t}$ peaks in those units (Appendix Figure, https://wwwnc.cdc.gov/EID/ article/27/3/20-4079-App1.pdf). $\mathrm{R}_{\mathrm{t}}$ decreased over time, to $\approx 1.0$ during most of May.

\section{Conclusions}

We found a shorter serial interval for COVID-19 in this prison than that estimated for Brazil overall

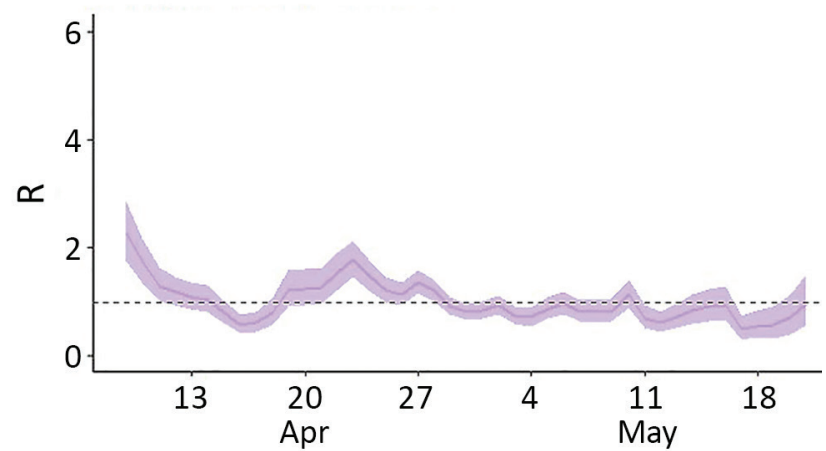

Figure 2. $R_{t}$ for severe acute respiratory syndrome coronavirus 2 transmission in a penitentiary complex, Brasília, Brazil, April-May 2020. Blue line indicates median $R_{t}$; blue shading indicates $95 \%$ Cl. Dashed line indicates $R_{t}=1$.
(9). This finding supports the idea of a faster viral spread in overcrowded settings, and considering that the estimated serial interval was lower than the mean incubation period, the likely transmission of presymptomatic cases might have played an important role in viral spread inside the prison complex $(10,11)$. Asymptomatic or presymptomatic cases, other sources of infection, or inmates failing to report symptoms might have affected accurately identifying primary infected inmates, resulting in our possibly underestimating the serial interval, $R_{t^{\prime}}$ or both. Considering the overcrowded conditions in the penitentiary complex and the impossibility of mandating effective social distancing, implementing broad testing strategies is fundamental for accurately measuring viral spread and planning better interventions.

The opinions expressed by authors do not necessarily reflect the opinions of the Ministry of Health of Brazil or the institutions with which the authors are affiliated.

\section{About the Author}

Dr. Gouvea-Reis is a fellow at the Field Epidemiology Training Program, Ministry of Health, Brazil. His research interests include global health, infectious diseases, and epidemiology.

\section{References}

1. Sánchez A, Simas L, Diuana V, Larouze B. COVID-19 in prisons: an impossible challenge for public health? [in Portuguese]. Cad Saude Publica. 2020;36:e00083520. https:/ / doi.org/10.1590/0102-311x00083520

2. Dolan K, Wirtz AL, Moazen B, Ndeffo-Mbah M, Galvani A, Kinner SA, et al. Global burden of HIV, viral hepatitis, and tuberculosis in prisoners and detainees. Lancet. 2016;388:1089-102. https:/ / doi.org/10.1016/ S0140-6736(16)30466-4

3. Burki T. Prisons are "in no way equipped" to deal with COVID-19. Lancet. 2020;395:1411-2. https://doi.org/ 10.1016/S0140-6736(20)30984-3

4. Kinner SA, Young JT, Snow K, Southalan L, Lopez-Acuña D, Ferreira-Borges $\mathrm{C}$, et al. Prisons and custodial settings are part of a comprehensive response to COVID-19. Lancet Public Health. 2020;5:e188-9. https:/ / doi.org/10.1016/ S2468-2667(20)30058-X

5. Departamento Penitenciário Nacional. National survey of penitentiary information [in Portuguese] [cited 2020 Sep 21]. https://www.gov.br/depen/pt-br/sisdepen

6. Ministério da Saúde. Coronavirus panel [in Portuguese] [cited 2020 Sep 21]. https:/ / covid.saude.gov.br

7. Conselho Nacional De Justiça [Internet]. CNJ renews Recommendation no. 62 for another 90 days and releases new data [in Portuguese] [cited 2020 Sep 21]. https:/ / www. cnj.jus.br/cnj-renova-recomendacao-n-62-por-mais-90dias-e-divulga-novos-dados

8. Secretaria de Saúde do Distrito Federal. Epidemiologic bulletin for 01.05.2020: public health emergency COVID-19 
within the Federal District [in Portuguese] [cited 2020 Sep 21]. http:/ / www.saude.df.gov.br/wp-conteudo/ uploads/2020/03/Boletim-COVID_DF-01-05-2020.pdf

9. Prete CA, Buss L, Dighe A, Porto VB, Candido DS, Ghilardi F. et al. Serial interval distribution of SARS-CoV-2 infection in Brazil. J Travel Med. 2020:taaa115. https://doi.org/10.1093/jtm/taaa115

10. Lauer SA, Grantz KH, Bi Q, Jones FK, Zheng Q, Meredith HR, et al. The incubation period of coronavirus disease 2019 (COVID-19) from publicly reported confirmed cases: estimation and application. Ann Intern Med. 2020;172:577-82. https:// doi.org/10.7326/ M20-0504
11. Backer JA, Klinkenberg D, Wallinga J. Incubation period of 2019 novel coronavirus (2019-nCoV) infections among travellers from Wuhan, China, 20-28 January 2020. Euro Surveill. 2020;25:2000062. https:/ / doi.org/10.2807/15607917.ES.2020.25.5.2000062

Address for correspondence: Fernando Gouvea Reis, EpiSUS-Programa de Epidemiologia de Campo Aplicada aos Serviços do SUS, Secretaria de Vigilância em Saúde, Ministério da Saúde. Edifício PO700, 6 andar, SRTV 702, Via W 5 Norte, Brasília, DF, Brazil; email: fernando.reis@saude.gov.br

\section{February 2020} Coronaviruses

- Middle East Respiratory Syndrome Coronavirus Transmission

- Acute Toxoplasmosis among Canadian Deer Hunters Associated with Consumption of Undercooked Deer

- Public Health Program for Decreasing Risk for Ebola Virus Disease Resurgence from Survivors of the 2013-2016 Outbreak, Guinea

- Characteristics of Patients with Acute Flaccid Myelitis, United States, 2015-2018

- Illness Severity in Hospitalized Influenza Patients by Virus Type and Subtype, Spain, 2010-2017

- Exposure to Ebola Virus and Risk for Infection with Malaria Parasites, Rural Gabon

- Cost-effectiveness of Screening Program for Chronic Q Fever, the Netherlands

- Unique Clindamycin-Resistant Clostridioides difficile Strain Related to Fluoroquinolone-Resistant Epidemic BI/RT027 Strain

- Porcine Deltacoronavirus Infection and Transmission in Poultry, United States

- Chronic Human Pegivirus 2 without Hepatitis C Virus Co-infection

- Interspecies Transmission of Reassortant Swine Influenza A Virus Containing Genes from Swine Influenza $A(\mathrm{H} 1 \mathrm{~N} 1)$ pdm09 and $A(H 1 N 2)$ Viruses

- Influence of Rainfall on Leptospira Infection and Disease in a Tropical Urban Setting, Brazil

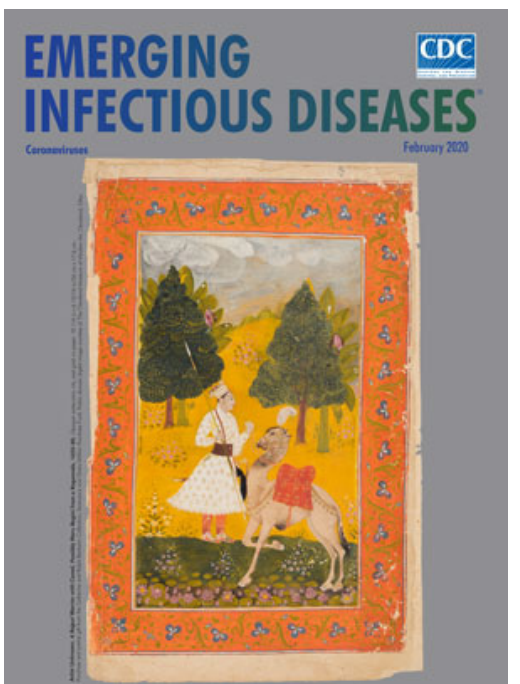

- Multiplex Mediator Displacement Loop-Mediated Isothermal Amplification for Detection of Treponema pallidum and Haemophilus ducreyi

- Novel Subclone of CarbapenemResistant Klebsiella pneumoniae Sequence Type 11 with Enhanced Virulence and Transmissibility, China

- Neutralizing Antibodies against Enteroviruses in Patients with Hand, Foot and Mouth Disease

- Systematic Hospital-Based Travel Screening to Assess Exposure to Zika Virus

- Rapid Nanopore Whole-Genome Sequencing for Anthrax Emergency Preparedness
- Elizabethkingia anophelis Infection in Infants, Cambodia, 2012-2018

- Global Expansion of Pacific Northwest Vibrio parahaemolyticus Sequence Type 36

- Surge in Anaplasmosis Cases in Maine, USA, 2013-2017

- Emergence of Chikungunya Virus, Pakistan, 2016-2017

- Mycoplasma genitalium Antimicrobial Resistance in Community and Sexual Health Clinic Patients, Auckland, New Zealand

- Early Detection of Public Health Emergencies of International Concern through Undiagnosed Disease Reports in ProMED-Mail

- Ocular Spiroplasma ixodetis in Newborns, France

- Use of Surveillance Outbreak Response Management and Analysis System for Human Monkeypox Outbreak, Nigeria, 2017-2019

- Human Norovirus Infection in Dogs, Thailand

- Hepatitis E Virus in Pigs from Slaughterhouses, United States, 2017-2019

- Rickettsia mongolitimonae Encephalitis, Southern France, 2018

- Human Alveolar Echinococcosis, Croatia

- Two Cases of Newly Characterized Neisseria Species, Brazil

- Hepatitis A Virus Genotype IB Outbreak among Internally Displaced Persons, Syria 